\title{
Pencegahan Konstipasi pada Ibu Nifas dengan Early Exercise
}

\author{
Uliyatul Laili*, Fauziyatun Nisa \\ Prodi DIII Kebidanan, Fakultas Keperawatan dan Kebidanan, \\ Universitas Nahdlatul Ulama Surabaya \\ ^Email Korespondensi: uliyatul.laili@unusa.ac.id
}

Article Info

Article history:

Submitted: 2019-05-07

Accepted: 2019-05-16

Published: 2019-08-31

Keywords:

Early exercise; constipation;

Postpartum;

\section{ABSTRACT}

In Indonesia, many postpartum mothers experience constipation.

Some of the contributing factors include less of movement after childbirth (early mobilization), poor nutritional intake, low fluid intake, narcotic-containing pain relievers leaving the intestines and periodic spasms of the small intestine. The purpose of this study was to find out the effect of giving care in the form of early exercise or early physical exercise in an effort to prevent constipation during the puerperium. The research method used was quasi-experiment; with the population were postpartum mothers on the first day up to the fifth day. Data collections were done by questionnaire and observations then tested by Mann Whitney test. The result of this study is that there was no effect between giving care in the form of early exercise to the incidence of constipation in postpartum mothers, a significance value of $0.678>0.005$. The conclusion of this study is that there were many other factors that influence the incidence of constipation in addition to activity factors, namely anxiety, suture injuries, current and past labor history and nutritional intake.

\section{ABSTRAK}

Kata Kunci:

Mobilisasi Dini; Konstipasi; Ibu Nifas;
Di Indonesia banyak ibu postpartum yang mengalami susah buang air besar. Beberapa faktor penyebab yang mempengaruhi antara lain kurangnya gerak setelah melahirkan (mobilisasi dini), asupan nutrisi kurang baik, asupan cairan yang rendah, obat pereda sakit yang mengandung narkotik meninggalkan tonus dan spasme periodic usus halus. Tujuan dari penelitian ini adalah untuk melihat pengaruh pemberian asuhan berupa early exercise atau latihan fisik secara dini dalam upaya pencegahan konstipasi pada masa nifas. Metode penelitian yang digunakan adalah quasy eksperimen, dengan populasi adalah ibu nifas pada hari pertama sampai dengan hari kelima. Pengumpulan data dilakukan dengan kuesioner dan observasi kemudian dilakukan uji dengan uji mann whitney. Hasil dari penelitian ini adalah tidak terdapat pengaruh antara pemberian asuhan berupa early exercise terhadap kejadian konstipasi pada ibu nifas, nilai signifikansi $0,678>0,05$. Kesimpulan dari penelitian ini adalah banyak faktor lain yang berpengaruh terhadap kejadian konstipasi selain faktor aktifitas, yaitu kecemasan, luka jahitan, riwayat persalinan sekarang dan yang lalu serta asupan nutrisi. 


\section{PENDAHULUAN}

Di Indonesia banyak ibu postpartum yang mengalami susah buang air besar. Beberapa faktor penyebab yang mempengaruhi antara lain kurangnya gerak setelah melahirkan (mobilisasi dini), asupan nutrisi kurang baik, asupan cairan yang rendah, obat pereda sakit yang mengandung narkotik meninggalkan tonus dan spasme periodic usus halus. ${ }^{1}$ Pada seseorang yang mengalami konstipasi, tinja akan menjadi lebih padat dan mengeras, menyebabkan makin susahnya defekasi, sehingga berdampak kontraksi uteri lembek, infeksi, lamanya penyembuhan luka jahitan, dan ambeien. ${ }^{2}$ Pada tahun 2007 ibu nifas yang mengalami konstipasi 33\% dari 103 ibu nifas. ${ }^{3}$ Rasa nyeri yang dirasakan oleh ibu postpartum kadangkala menyebabkan keengganan untuk berkemih, tetapi usahakanlah untuk berkemih secara teratur, karena kandung kemih yang penuh dapat menyebabkan gangguan kontraksi rahim sehingga dapat menyebabkan perdarahan. Oleh karena itu, diharapkan ibu postpartum dapat segera melakukan Buang Air Kecil (BAK) dan Buang Air Besar (BAB) agar tidak mempengaruhi proses involusi uterus.

Asuhan pada ibu postpartum yang dapat dilakukan untuk mengatasi masalah konstipasi yaitu dengan cara memfasilitasi ibu untuk membicarakan masalah yang dihadapi pada ibu nifas dengan bersikap proaktif menanyakan pada ibu mengenai masalah yang terjadi termasuk biasanya adalah masalah kontrol defekasi. ${ }^{4}$ Hal yang bisa dilakukan untuk mengurangi konstipasi adalah dengan sesegera mungkin melakukan mobilisasi dini setelah melahirkan. ${ }^{5}$ Selain itu mobilisasi dini, ibu juga dapat diajarkan gerakan yang lebih teratur yaitu dengan early exercise yang merupakan latihan fisik secara sederhana dengan gerakan teratur dan dilakukan secara bertahap. Beberapa manfaat yang oleh ibu postpartum dengan segera melakukan early exercise adalah dapat mempercepat pulihnya alat-alat kandungan, mengurangi kejadian komplikasi kandung kemih, thrombosis vena purperalis, dan emboli pulmonal serta banyak mengurangi keluhan pada sistem pencernaan dan perkemihan.

Selain dengan melakukan latihan fisik secara teratur, asupan nutrisi terutama serat yang dikonsumsi oleh ibu selama masa nifas juga sangat mempengaruhi terjadi konstipasi. Makanan yang memiliki kandungan serat tinggi dapat membantu mempercepat proses defekasi pada ibu nifas. Akan tetapi hal tersebut tetap harus memperhatikan jumlah dan jenis serat yang di konsumsi. ${ }^{6}$ Tujuan penelitian ini adalah untuk mengetahui pengaruh dari pemberian asuhan berupa early exercise dalam pencegahan konstipasi pada ibu nifas.

\section{METODE PENELITIAN}

Desain penelitian yang digunakan adalah Quasi Eksperimental. Populasi dan sampel penelitian adalah ibu postpartum hari pertama sampai hari kelima yang diambil menggunakan teknik purpossive sampling. Variabel independennya yaitu metode early exercise sedangkan variabel dependennya adalah pencegahan konstipasi. Berdasarkan jumlah sampel yang sudah ditetapkan, peneliti mengelompokkan sampel (ibu postpartum) dalam kelompok kontrol dan kelompok perlakuan yaitu kelompok akan diajarkan early exercise. Kriteria inklusi dalam penelitian ini adalah ibu nifas dengan riwayat persalinan normal, tidak ada masalah/ komplikasi selama kehamilan, persalinan, nifas. Peneliti melakukan pendekatan dengan ibu postpartum yang menjadi kelompok perlakuan dan menjelaskan tentang early exercise serta melakukan informed consent. Kemudian ibu postpartum diajarkan early exercise yaitu latihan fisik dengan gerakan fisik sederhana sesuai 
dengan SOP (Standar Operasioanl Prosedur) yang sudah dibuat, dilakukan setiap hari selama 3 hari masa nifas oleh tenaga terlatih. Selanjutnya dilakukan dengan analisa data dengan menggunakan uji mann whitney dengan tujuan untuk membandingkan antara kelompok kontrol dan perlakuan. Lokasi penelitiannya adalah di BPM di Sidoarjo.

\section{HASIL PENELITIAN}

Setelah data penelitian dianalisis maka diperoleh hasil sebagai berikut:

Tabel 1: Distribusi Frekuensi Berdasarkan Pendidikan dan Paritas

\begin{tabular}{lcccc}
\hline Karakteristik & $\begin{array}{c}\text { Kelompok } \\
\text { Kontrol }\end{array}$ & $\begin{array}{c}\text { Kelompok } \\
\text { Perlakuan }\end{array}$ & Frekuensi (f) & $\begin{array}{c}\text { Persentasi } \\
(\%)\end{array}$ \\
\hline Pendidikan & & & & \\
Dasar & 0 & 0 & 0 & 0 \\
Menengah & 13 & 11 & 24 & 67 \\
$\quad$ Tinggi & 5 & 7 & 12 & 33 \\
\hline Total & 18 & 18 & 36 & 100 \\
\hline Paritas & & & & \\
Primipara & 5 & 5 & 10 & 28 \\
Multipara & 12 & 13 & 25 & 69 \\
$\quad$ Grandemultipara & 1 & 0 & 1 & 3 \\
\hline Total & 18 & 18 & 36 & 100 \\
\hline
\end{tabular}

Berdasarkan tabel 1, diketahui bahwa sebagian besar ibu nifas $67 \%$ memiliki pendidikan menengah. Sedangkan untuk tabel frekuensi paritas pada ibu nifas menunjukkan bahwa sebagian besar ibu nifas adalah kelompok multipara yaitu telah melahirkan lebih dari 1 kali sebanyak 25 orang atau $69 \%$.

Tabel 2: Analisa Data Early Exercise terhadap Pencegahan Konstipasi

\begin{tabular}{cccccc}
\hline Kejadian & \multicolumn{2}{c}{ Kelompok Kontrol } & \multicolumn{2}{c}{ Kelompok Perlakuan } & \multirow{2}{*}{ Nilai $\mathbf{p}$} \\
\cline { 2 - 5 } Konstipasi & $\mathbf{n}$ & $\%$ & $\mathbf{n}$ & $\%$ & \\
\hline Konstipasi & 4 & 22,0 & 3 & 17,0 & 0,678 \\
Tidak konstipasi & 14 & 78,0 & 15 & 83,0 & \\
\hline Total & 18 & 100,0 & 18 & 100,0 & \\
\hline
\end{tabular}

Berdasarkan hasil tabulasi silang pada tabel diatas dapat diketahui bahwa responden pada kelompok kontrol dan mengalami konstipasi sebanyak 14 orang atau $39 \%$ dan yang tidak mengalami konstipasi sebanyak 4 responden atau $11 \%$. Sedangkan responden pada kelompok eksperimen dan mengalami konstipasi sebanyak 15 orang atau $41,7 \%$ dan yang tidak mengalami konstipasi sebanyak 3 responden atau $8,3 \%$.

Berdasarkan hasil pengujian statistik di atas dapat diketahui bahwa nilai signifikansi 0,678 $>0,05$, sehingga dapat disimpulkan bahwa tidak ada perbedaan konstipasi antara kelompok eksperimen dan kontrol

\section{PEMBAHASAN}

Berdasarkan hasil penelitian didapatkan bahwa pada ibu yang diberikan asuhan early exercise dibandingkan dengan yang mendapatkan suhan secara standart tidak ada perbedaan yang signifikan. Hal ini bisa dipengaruhi oleh banyak hal, diantaranya adalah paritas ibu, dan pengalaman yang diperoleh ibu dari 
persalinan sebelumnya. Selain itu, faktor nutrisi dan luka jahitan perineum juga berpengaruh terhadap kecemasan ibu untuk melakukan defekasi.

Penelitian yang dilakukan oleh Woodley SJ dkk, menunjukkan hasil yang sama, yakni bahwa Pelvic floor muscle training yang dilakukan pada ibu nifas, tidak dapat menggambarkan pencegahan kejadian konstipasi. Pada penelitian tersebut dijelaskan bahwa banyak faktor yang harus diperhatikan dalam prosesnya, termasuk data sensus ekonomi kesehatan. ${ }^{7}$

Selain dengan melakukan latihan fisik, faktor lain yang mungkin juga harus diperhatikan adalah faktor paritas. Karena paritas ini yang akan membentuk pengalaman pada ibu nifas mengenai persalinan yang lalu. Sehingga pada umumnya ibu pripipara cenderung lebih takut dan khawatir dengan pengalaman barunya pada masa nifas dibandingkan dengan ibu yang sudah beberapa kali melahirkan.

Salah satu gerakan dari early exercise adalah gerakan dalam mengelola dasar panggul. Pada studi sistematik review yang dilakukan oleh Deffieux $X$ mengenai gerakan dasar panggul menunjukkan hasil bahwa hasil terapi otot dasar panggul direkomendasikan untuk inkontinensia perkemihan atau konstipasi pada 3 bulan setelah melahirkan. ${ }^{8}$ Penelitian ini didukung oleh penelitian lain yaitu Summary of International Guidelines for Physical Activity Following Pregnancy oleh Kelly R. Evenson, yang menunjukkan bahwa beberapa Negara juga mempunyai aturan dalam melakuakn aktifitas fisik pada masa nifas, karena banyak memberikan manfaat diantaranya yaitu meningkatkan kesehatan mental, menurunkan kejadian depresi postpartum serta meningkatkan kardiorespiratori. Aktifitas fisik ini dilakukan dengan rekomendasi tertentu yaitu dilakukan lebih dari sama dengan 15 menit setiap sesi, senam dasar panggul untuk waktu kurang dari 6 bulan postpartum dan selanjutnya dapat dilakukan dengan aerobuk atau lari. ${ }^{9}$

Latihan fisik sederhana pada masa nifas akan dapat memberikan banyak manfaat apabila dalam pelaksanaannya tidak hanya awal masa nifas (early exercise), akan tetapi dilanjutkan dengan asuhan berupa aktifitas fisik lanjutan. Hal ini sesuai dengan penelitian yang dilakukan oleh Michelle F. Mottola, yang menjelaskan bahwa Periode asuhan pada masa nifas seharusnya dilakukan hingga 1 tahun, tidak hanya $6-8$ minggu saja untuk menilai hasilnya, karena banyak peruahan fisiologis yang terjadi pada masa itu dan sampai waktu menyusui selesai. ${ }^{10}$

\section{SIMPULAN DAN SARAN}

Simpulan dari hasil penelitian ini yaitu tidak terdapat pengaruh early exercise terhadap proses involusi uterus dan kejadian konstipasi. Hasil penelitian ini dapat menjadi bahan kajian untuk dapat meningkatkan pelayanan dalam memberikan asuhan pada masa nifas dengan membantu ibu untuk segera melakukan gerakan fisik sederhana dan teratur, sehingga dapat meningkatkan derajat kesehatan ibu dan anak.

\section{UCAPAN TERIMA KASIH}

Penulis menyampaikan terima kasih kepada PMB Ika M dan PMB Nanik yang sudah membantu dalam penelitian ini.

\section{DAFTAR PUSTAKA}

1. Reiss U, Reiss MY. Menjadi lbu Bahagia Pasca Persalinan. Jogjakarta: Luna Publisher; 2008.

2. Mansjoer A, Askariasis. Dalam : Kapita Selekta Kedokteran. Jilid 1. Edisi 3. Jakarta: 
Media Aesculapius FKUI; 2010.

3. Bradley CS, Kennedy CM, Turcea AM, Rao SSC, Nygaard IE. Constipation in Pregnancy. Obstet Gynecol [Internet]. Desember 2007;110(6):1351-7. Tersedia pada: http://journals.Iww.com/00006250-200712000-00022

4. Fraser D, Cooper M, A M. Buku Ajar Bidan Myles. Jakarta: EGC; 2009.

5. Ambarwati ER. Asuhan Kebidanan Nifas. Yogyakarta: Mitra Cendekia; 2011.

6. Uliyah M, Ahmad H. Keterampilan Dasar Praktik Klinik untuk Kebidanan. Jakarta: Salemba Medika; 2008.

7. Woodley SJ, Boyle R, Cody JD, Mørkved S, Hay-Smith EJC. Pelvic Floor Muscle Training for Prevention and Treatment of Urinary and Faecal Incontinence in Antenatal and Postnatal Women. Cochrane Database Syst Rev [Internet]. 22 Desember 2017;12(12). Tersedia pada: http://doi.wiley.com/10.1002/14651858.CD007471.pub3

8. Deffieux X, Vieillefosse S, Billecocq S, Battut A, Nizard J, Coulm B, et al. Postpartum Pelvic Floor Muscle Training and Abdominal Rehabilitation: Guidelines. J Gynécologie Obs Biol la Reprod [Internet]. Desember 2015;44(10):1141-6. Tersedia pada: https://linkinghub.elsevier.com/retrieve/pii/S036823151500263X

9. Evenson KR, Mottola MF, Owe KM, Rousham EK, Brown WJ. Summary of International Guidelines for Physical Activity After Pregnancy. Obstet Gynecol Sur [Internet]. Juli 2014;69(7):407-14. Tersedia pada: http://journals.Iww.com/00006254201407000-00016

10. Mottola MF. Exercise in the Postpartum Period. Curr Sports Med Rep [Internet]. Desember 2002;1(6):362-8. Tersedia pada: http://journals.Iww.com/00149619200212000-00010 